\title{
City centre masterplanning and cultural spaces: A case study of Sheffield
}

Received (in revised form): 15 September 2006

\section{Kirsten Holmes}

is a Lecturer in Tourism at the University of Surrey. Previously, she worked at the University of Sheffield teaching MA Arts and Heritage Management. Her research focuses on various aspects of cultural and heritage tourism, including museum visiting, volunteering in museums, leisure, sport and tourism and human resource management in museums. She has published several book chapters and journal articles, including papers in Tourism Management, the International Journal of Heritage Studies and Museum Management and Curatorship.

\section{Yasminah Beebeejaun}

is a Senior Lecturer in Planning and Architecture at the University of the West of England. She completed her doctoral studies at the University of Sheffield where she investigated the construction of identity in plan-making processes. Her research interests include the tensions between community, participation and planning (particularly, master planning), and she has published her research in Planning Theory and Practice.

\section{Abstract}

This paper presents a case study of Sheffield city centre's masterplan, focusing on the Heart of the City civic core. Sheffield was one of the first city councils to use culture as a basis for economic regeneration. The literature argues that while early regeneration was economically driven, under New Labour cultural planning has become more focused on creating inclusive spaces. The new developments in Sheffield associated with the masterplan have been in two stages. The first created award winning public cultural spaces, including the Millennium Galleries and Winter Garden. The second phase has led to private, commercial developments, which this paper argues have impacted negatively on the public spaces. The public spaces do not meet the inclusive aspirations of either Sheffield's local strategic partnership or cultural policy. The Sheffield case, however, demonstrates how all regeneration is located within local economic realities. As a secondary city within its region, in terms of office rents, there is a limit to what the public sector in Sheffield can demand from the private sector. The masterplan's developments are ongoing and there is evidence that as office rentals are increasing the public sector could exert more power in the future.

Kirsten Holmes School of Management University of Surrey Guildford, Surrey GU12 6JZ, UK Tel: +44 (o) 1483682013 E-mail:k.holmes@surrey.ac.uk

\section{Keywords:}

cultural industries, masterplanning, public spaces, regeneration

Journal of Retail and Leisure Property (2007) 6, 29-46. doi:10.1057/palgrave.rlp.5100042 


\section{INTRODUCTION}

During the 1980s, prestigious cultural attractions were viewed by local authorities across Europe as a focus for regenerating areas facing economic decline. These cultural flagships could attract investment and new jobs in their construction and operation; contribute to a new identity for the region and, through tourism, generate additional income and visitors. ${ }^{1}$ Unlike some other post-industrial cities, Sheffield does not have a wealth of obvious cultural attractions in the city centre. Sheffield city council, however, was one of the first local authorities in the UK to turn to the cultural industries as an alternative source of employment creation and urban regeneration, and the use of culture in Sheffield's regeneration is the focus of this paper.

Sheffield lies approximately 170 miles north of London, within Yorkshire, although a third of the city is located within the Peak District National Park. The city's population stands at $516,100 .^{2}$ The decline of the manufacturing sector in the 1980s had huge impacts on Sheffield's steel industry with employment in the sector declining 60 per cent between 1971 and 1997 (Moss, ${ }^{3}$ p 212). Responses to these economic changes demonstrate the particular type of local politics Sheffield has been characterised for and which has operated largely under the Labour party's control. It has been categorised as paternalistic and interventionist. This is illustrated through the housing tenure profile in Sheffield where in 2005 nearly 23 per cent of the population rented from the local authority compared to a national average of just under 11.5 per cent. ${ }^{4}$

The city council's paternalistic approach can be observed within the local economy, with cultural policy interventions traceable back to the early 1980s, in contrast to the national Conservative government's laissez-faire approach (Moss, ${ }^{3} \mathrm{p}$ 212). While DiGaentano and Lawless argue that the realities in the local state's intervention in the market, for example, through the creation of an Employment Department within the city council lacked sufficient resources to manage the fate of the city, the reality of intervention was a long way divorced from the rhetoric; the latter had one obvious effect, it dampened any enthusiasm the market had for investing in the city. Hardly any development took place in the city in the first half of the 1980s. ${ }^{5}$ This contrasts markedly with the development of Leeds, a neighbouring city, which between 1981 and 1998 saw over 52,000 jobs created and the workforce grow by 17 per cent through partnership with the private sector. ${ }^{6}$

Nonetheless, key agencies within the city have been promoting Sheffield, as a creative city that was able to bring about renewal through building on this legacy. ${ }^{7,8}$ Not all cultural developments have been a success, however. While Sheffield's earlier investment in the Cultural Industries Quarter (CIQ) was pioneering, ${ }^{3,9}$ the lottery-funded National Centre for Popular Music was unpopular with local residents and was derided in both local and national press, ${ }^{10}$ and unfortunately it closed in 2001, after costing more than $£ 15$ million. Since Meadowhall, a major retail centre, opened nearby in 1990, Sheffield city centre has struggled commercially. This has only compounded the problems caused by the decline in traditional industry, council funding cuts and restructuring that threatened many of the city centre's existing cultural facilities. In response to this, Sheffield city council launched an urban regeneration 
partnership in 2000, with the responsibility of implementing a city centre masterplan. This aims to improve the city's economy, particularly with the creation of new jobs and improvements in the property market, the retail, leisure and cultural facilities in the city centre and the city's transport system. Cultural attractions are only a part of the overall masterplan; however, these are some of the most visible changes to local residents and visitors alike. Two of the major cultural facilities built as part of the masterplan are the Millennium Galleries and Winter Garden, which have both been fêted with several awards. ${ }^{11}$ Yet, as the masterplan has progressed, concerns have been raised about the apparent semiprivatisation of public space. This reflects the city's politics, which since the 1920s and certainly until the 1990s have been firmly controlled by the Labour Party and Trade Unionism contrasting with other cities such as Birmingham. ${ }^{5}$

This paper presents a case study of Sheffield's city centre masterplan, focusing on the Heart of the City, civic core. In particular, the paper examines how this creates cultural spaces for residents and visitors, and the tensions that arise from this process. As Amin et al. emphasise "All spaces embody power relations of some sort - even so-called public spaces (urban parks for instance) are more 'accessible (in many tangible and intangible ways) to some groups...than others.' (Amin et al., ${ }^{12} \mathrm{p} 12$ ). While masterplanning is understood to present tangible improvements to cities and various user groups, it raises questions regarding the impacts of large-scale planning processes upon the accessibility of the public realm to the individual. ${ }^{13}$

\section{CULTURAL REGENERATION AND FLAGSHIP PROJECTS}

The economic restructuring of cities in the 1970s and 80s; an increase in people's disposable income for leisure; and decentralisation of government powers resulted in cultural policy being used as a means for regenerating city centres and diversifying their economies. ${ }^{14}$ Cultural regeneration of deindustrialised cities and regions was not, however, simply a means of developing a new economic base. Culture was also a means of improving the city's image and reality for residents and visitors. The new service industries gave rise to the service class, professional employees of cultural services, who were also the primary consumers. ${ }^{15}$ An influx of the service class was seen as a means of gentrifying run down areas and communicating their values to the other residents since education, journalism and advertising are service class industries. Local governments wanted to attract the service class to their city centres as a means of transforming a depressed place into somewhere that people lived, worked and spent their leisure time. This could be either by attracting new businesses and thus encouraging people to move to the city, or through tourism by attracting members of the service class on short breaks. ${ }^{15}$

Flagship cultural projects were a major part of regional and local governments' plans to rebrand their city and attract tourists. An often cited example is the Guggenheim Museum in Bilbao. Bilbao suffered not only from industrial decline but also from a negative image due to 
its association with the terrorist group ETa.${ }^{16}$ There is no doubt that the iconic Frank Gehry-designed art gallery, which opened in 1998, has become a symbol for the city and has successfully attracted tourists, turning Bilbao into a popular weekend destination, serviced by several low-cost airlines. ${ }^{17}$ The benefits of the Guggenheim Museum for the residents of Bilbao and the Basque Country, however, are debatable. The Guggenheim Museum was an expensive project, and researchers question whether the cultural life of the Basque Country might not have been better served by investing the money in local arts and artists. ${ }^{18,19}$ This corresponds with Bianchini and Parkinson's conclusions that regeneration based around prestige attractions does little to benefit the disadvantaged members of the community. ${ }^{20}$

Early cultural regeneration projects failed to integrate low income and ethnic minority groups culturally, socially or spatially. ${ }^{20}$ In the late 1990 s and early 2000s, cultural regeneration moved from focusing on economic benefits to considering culture as an agent of social change in response to the Labour Government's emphasis on social inclusion. Under New Labour, culture-led regeneration is concerned with how people live in places and that the city centre is 'at the heart of the way in which social inclusion/exclusion are conceptualised within cultural planning' (Stevenson, ${ }^{21} \mathrm{p}$ 127). Cultural regeneration around Newcastle's Quayside has helped restore local people's identities as well as improve the fabric and culture of the city centre. ${ }^{22}$ Bailey et al. argue that 'culture led regeneration perhaps provides a framework within which...local people can re-establish ownership of their own sense of place and space' (Bailey et al., ${ }^{22} \mathrm{p}$ 49). The new developments including the Angel of the North statue and the Baltic Centre appear, in the early stages of a ten-year longitudinal study, to have increased local pride in the city. The study includes residents living in areas of deprivation, some way from the attractions themselves but nearly two-thirds of residents have made a special trip to visit many of these new attractions. The authors argue that the reason for these successes is that local residents took ownership of these new developments as a 'source of local pride' (Bailey et al., ${ }^{22} \mathrm{p}$ 61). They conclude that culture-led regeneration need not be elitist but can be for everyone in the city. It is not clear, however, whether these findings can be transferred from Newcastle, a major city within its region to Sheffield, one of many cities in Yorkshire, whose residents may not have so distinctive a local identity as Tyneside residents. ${ }^{23}$

This concurs with Stevenson's claim that cultural planning under New Labour is a means of creating 'redeveloped urban space [which] will become the public sphere wherein citizenship is expressed and social inclusion affirmed' (Stevenson, ${ }^{21} \mathrm{p}$ 128). Indeed, the Labour Government in the UK emphasised its concern with public spaces by setting up the Commission for Architecture and the Built Environment (CABE) in 1999, as a non-departmental public body to 'champion well-designed buildings and public space' ${ }^{24}$

Yet, while city centres might be regenerated, how far have the lowincome residents living in run down housing estates on the periphery of the city centre shared in this renaissance? Bianchini identified a growing 
gap between 'lively, convivial city centres in which cultural activities are flourishing and increasingly marginalised peripheries' (Bainchini, ${ }^{20}$ p 201). Planners need to develop open-minded space, designed for many uses, where citizens tolerate each other. ${ }^{25}$ How far has Sheffield's city centre masterplan achieved this?

\section{CULTURAL REGENERATION AND SHEFFIELD CITY CENTRE}

Cultural policy and urban regeneration have been closely linked since the 1980s, when national and regional governments looked for an alternative economic base to the traditional manufacturing industries, which were beginning to decline. Sheffield and steel have a long history, and steel production and metalworking were the main economic base and source of employment up until 1980. Outdated production processes, attempts to change industrial practices, overseas competition and industrial action led to the loss of 50,000 jobs in Sheffield in that year alone. The industrial workforce fell by 187,000 between 1971 and 1997, by which time 75 per cent of jobs were in the service sector. ${ }^{3}$

At the same time, Sheffield city council began to publicly fund cultural projects, including the CIQ and the Leadmill (a music performance venue). The CIQ was established to stimulate employment, enhance cultural provision and attract tourism. This project was visionary but Moss argues that this pioneering status has led to the CIQ ultimately failing to create a vibrant public space as so little was known at the time about successful cultural regeneration. ${ }^{3}$ For example, the location of the CIQ means that it is still some distance from the city centre.

Sheffield city council reassessed their cultural policy in the early 1990s and noted the problems of cultural segregation of the traditional arts venues, such as museums and theatres, from the contemporary arts production sites within the CIQ. The subsequent report recommended a more integrated approach to cultural planning. ${ }^{26}$ The report also noted that Sheffield was suffering from a series of infrastructure problems, including transport links, which meant that the city struggled both to attract tourists and new businesses, in sharp contrast to nearby Meadowhall.

During the 1990s, Sheffield's traditional cultural facilities faced inadequate financing, threats of closure and the very real closure of the city council's Arts Department. All of the council's cultural facilities were externalised from the council's direct control into a series of charitable trusts. The benefits and drawbacks of trust status are still under debate, ${ }^{27}$ but trust status has enabled both the independent Showroom cinema and Abbeydale Industrial Museum to reopen; the Millennium Galleries to be built and the City Museum and Mappin Art Gallery to be redeveloped, and Sheffield Theatres ${ }^{28}$ to achieve financial stability and international acclaim for its productions.

The introduction of the national lottery in 1994 and the subsequent availability of funds for new capital cultural projects changed the cultural landscape of the city. The council sought to use a flagship project 
to rejuvenate the CIQ and attract tourism and aimed to build on Sheffield's musical connections with the National Centre for Popular Music, the recipient of a $£ 11 \mathrm{~m}$ lottery grant. Unfortunately, the National Centre for Popular Music as a visitor attraction was a failure. ${ }^{27}$ The reasons for this include a consultant's report, which substantially overestimated the potential number of visitors $;^{29}$ an expensive entrance fee, not justified by the limited number of exhibits inside; a lack of parking in the vicinity; and poor press coverage, with claims that the attraction was elitist. ${ }^{10}$

Sheffield city council has recently launched its new cultural strategy, which sets the city's cultural direction up to $2016 .{ }^{30}$ The council's cultural vision for Sheffield is that it becomes 'a European centre for cultural excellence, where culture contributes to the development of successful individuals, thriving communities and a strong economy' and the 'vision will be achieved through the active participation and endeavours of our citizens, communities and businesses in an inclusive partnership that will deliver a vibrant image for Sheffield' (Gosse, ${ }^{30} \mathrm{p} 1$ ). The council also aims to secure a commitment to 'innovative and high quality design throughout the city's built environment, public realm, its green and open spaces...' (Gosse, ${ }^{30} \mathrm{p}$ 9).

Sheffield's cultural policy is therefore about creating inclusive, quality cultural spaces for residents. How compatible are these aims with those of the city centre masterplan?

\section{PHYSICAL REGENERATION AND SHEFFIELD CITY CENTRE}

Masterplanning is not a new concept and has been practised throughout the modern history of planning, from the Garden Cities of Howard to Keeble's neighbourhood designs. ${ }^{31}$ During the 1960s, however, the role of the planner as 'expert' was contested, and planning debates in the last few decades have become focused upon advocacy and then, communicative and collaborative planning. ${ }^{31,32}$ The masterplan nonetheless has emerged as a tool of the planning practitioner in guiding regeneration and redevelopment of urban spaces. Indeed, Bell has proposed three critical reasons for the resurgence of the masterplanning: ${ }^{13}$

'[F]irst, an increased emphasis on consumption uses in the local economy; secondly, a greater tendency by institutions and developers to hold an equity share in development; and thirdly, a shift towards larger development projects.' (Bell, ${ }^{13}$ p 96)

Sheffield is home of one of the three pilot urban regeneration companies (URCs), the other two being in other, northern post-industrial cities, Liverpool and East Manchester. ${ }^{33}$ URCs' powers are determined through Local Strategic Partnerships (LSPs). LSPs are partnerships between local public, private, community and voluntary organisations whose aim is to lead neighbourhood renewal. ${ }^{34}$ The city centre's LSP is Sheffield First, which sets out the following 12 key features that define a successful city for us (Sheffield, ${ }^{35} \mathrm{p} 9$ ): 
- strong economy

- vibrant city centre

- well connected

- high employment and high skills in a learning city

- an exceptional cultural and sporting city

- attractive, successful neighbourhoods

- great place to grow up

- good health and wellbeing for all communities

- low crime

- environmental excellence

- inclusive and cosmopolitan city

— well run and well regarded.

Sheffield's URC, Sheffield One, is the lead agency in delivering the new masterplan for the city, which divides the city centre into 10 different quarters, each with an individual but connected regeneration plan. Sheffield One is a partnership between Sheffield City council, Yorkshire Forward, the regional development agency and English Partnerships. URCs are conceptualised as delivery agents for specific strategic objectives within the city region.

It is too early to comment on the success or otherwise of URCs ${ }^{33}$ although central government clearly considers them to be a model for the future, having gone on to establish 20 more in the second round..$^{36}$ It is evident, however, that there are tensions between a community and voluntary sector agency (the LSP) being able to control the direction of a URC, which seeks to harness business interests that have a special position within the British planning system based upon land-ownership rights. ${ }^{37}$ Fainstein argues that these partnerships are inevitable:

'The local state necessarily becomes involved in the capitalist demand for a more efficient urban landscape, since capitalists cannot carry out the task of redevelopment on their own.' (Fainstein, ${ }^{37} \mathrm{p} 13$ ).

What is the nature, however, of the power relations within LSPs and URCs, and what is the relationship between them? The former Office of the Deputy Prime Minister's states that a successful URC includes 'Commitment by all parties to a URC Board chaired by a private sector representative and with no public sector majority.' (Office of the Deputy Prime Minister, $\left.{ }^{33} \mathrm{p} 15\right)$. This view of regeneration is contested, however, with Hart (Hart, ${ }^{38}$ p 244) arguing that:

'If the necessary new partnerships are to come about, the private sector may have to accept that a much slower rate of return is now the only sustainable way forward.'

Sheffield One's masterplan begins by setting out a new vision for Sheffield, proposing that Sheffield has the ability to become a $21 \mathrm{st}$ century city. According to Sheffield One, the city needs to capitalise on the natural environment surrounding it, and improve the local economy by both strengthening its current strong employment sectors and 
developing other sectors. This vision for Sheffield attempts to encompass the whole community, suggesting that this stronger economy will help lift people out of social exclusion and that the city redevelopment will provide safe and accessible spaces: 'The new city centre will provide something for everyone in a lively and ever changing environment.' (Koetter Kim \& Associates, ${ }^{39}$ p 13).

The vision foresees a vibrant, successful and economically competitive place, with the lifestyles of the city's residents enhanced by their new city. What kind of city centre is envisaged?

'High fashion, quality restaurants and bars, high quality food markets, weekend farmers' markets, and daily clothes and general goods markets will all be available within a short walking distance of each other. The discount shopping district will be a vibrant exciting place to bargain'. (Koetter Kim \& Associates, ${ }^{39}$ p 13)

The vision is of a public engaged in economic consumption albeit at a variety of income levels, concurrent with cultural regeneration plans in the 1980s, which sought to attract the service class. ${ }^{15}$ Yet, how has masterplanning conceived public and private spaces and what implications does this have for the city's users? The outset of the vision gives the residents of the city roles, either as an employee of one of the businesses in the re-imagined city or as an agent enjoying the consumptive spaces within the city, thus their roles are limited to the service class and cannot be described as inclusive.

The masterplan proposes 12 underpinning principles for regeneration and economic development. Four of these relate to the economy and include employment, retail and mixed use development, and four relate to the need for transport improvements to the city. The remaining four address the city in terms of public services and spaces, and include the aspiration for:

- A dynamic public and civic realm providing pleasing and high quality pedestrian environments through quality streets and squares and new buildings of architectural merit....

- A socially and economically accessible City centre offering opportunity for all Sheffield's residents to participate in and benefit from the wealth of opportunity and activities that define Sheffield as a unique and dynamic City offering an unparalleled quality of life.(Koetter Kim \& Associates, ${ }^{39}$ pp 14-15).

How have these two aspirations been expressed within the Heart of the City development?

\section{THE HEART OF THE CITY}

The Heart of the City is the civic core of Sheffield city centre and offers the potential to link together the primary shopping zones with the main 
cultural venues and attractions. The first phase of the Heart of the City redevelopment pre-dated the production of the masterplan, and started in 1996 through extensive landscaping and construction works to redevelop the Peace Gardens and demolish the city council's Town Hall Extension. New cultural attractions, the Millennium Galleries and the Winter Garden, along with the Peace Gardens were in progress or had been completed (Figure 1). ${ }^{40}$

In addition, there was an ambitious programme of new build private development, which is currently in progress and incorporates: ${ }^{40}$

- 200,000 square feet of office space

- 135,000 square feet of restaurant, bar and retail space

- 320 luxury apartments

- 4-star hotel

- 550 space car park

At this stage, one office block, Number One St Pauls has been completed comprising 72,000 square feet of office space, which has been pre-let to a law firm at a rental value of $£ 18$ per square foot (Town Reports ${ }^{41}$; see Table 1), along with a Café Rouge and a hotel, part of the Macdonald group. Thus, the first phase of the development concentrated on the production of the public and cultural spaces, whereas the second focused on the private and commercial buildings, and whose principal users will be the office workers and those able to afford the leisure opportunities offered by the commercial space. The divisions between these spaces and the public space of the Peace Gardens can already be observed by the number of tables and chairs set outside during the summer months for restaurant and bar patrons as opposed to the limited seating for public space users.

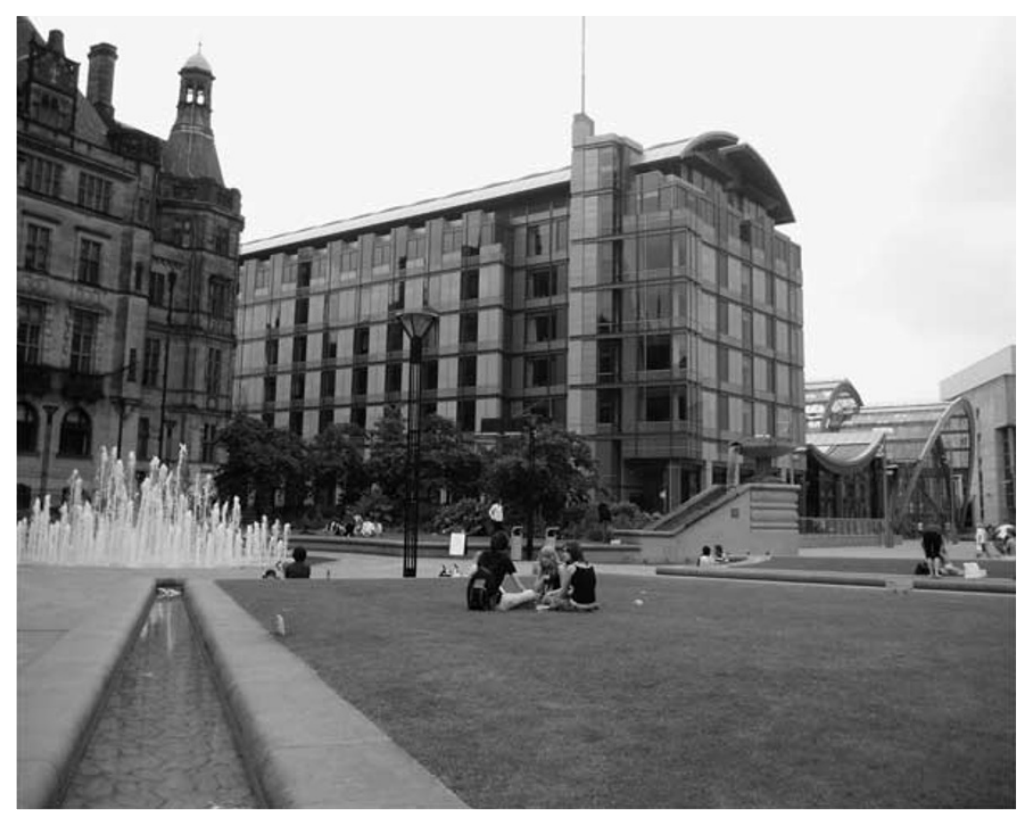

Figure I: The Peace Gardens, showing the Macdonald Hotel between the Town Hall and the Winter Garden 
The first principle of the masterplan highlighted above, that of creating 'a dynamic public and civic realm', has largely been achieved. The Heart of the City includes the town hall (the only Grade 1 listed building in Sheffield), the Peace Gardens and the two new flagship cultural attractions, the Winter Garden and the Millennium Galleries. The Peace Gardens have become a heavily used and popular pedestrian space. The Millennium Galleries, which opened in 2001, provides high-quality gallery exhibition space and attracts exhibitions from London and abroad. The building has won several awards for its architecture. The success of the Millennium Galleries and the organisation which manages it Sheffield Galleries and Museums Trust (SGMT) — can be illustrated by SGMT having been chosen as the hub museum for the Yorkshire region. That is, they are the lead museum in delivering the government's plans for improving regional museums. The Winter Garden (Figure 2), a temperate glasshouse completed in 2002, provides an undercover space in a building of architectural merit, having also won several awards, including a joint award with the Millennium Galleries from the Royal Institute of British Architects.

Sheffield is not the primary city within the region and has been unable to compete commercially with Leeds or Manchester; for example, Table 1 shows that office rentals in Sheffield are considerably lower than those in nearby cities. Although rents are rising, Knight Frank

Table I: Office space rental values at July $2005^{43}$

\begin{tabular}{lccr}
\hline Rent (Esqft/pa) & Leeds & Manchester & Sheffield \\
\hline $\begin{array}{lccr}\text { Office - Grade A } \\
\text { Retail - Zone A }\end{array}$ & 24 & 27.50 & 18 \\
& 310 & 300 & 210 \\
\hline
\end{tabular}

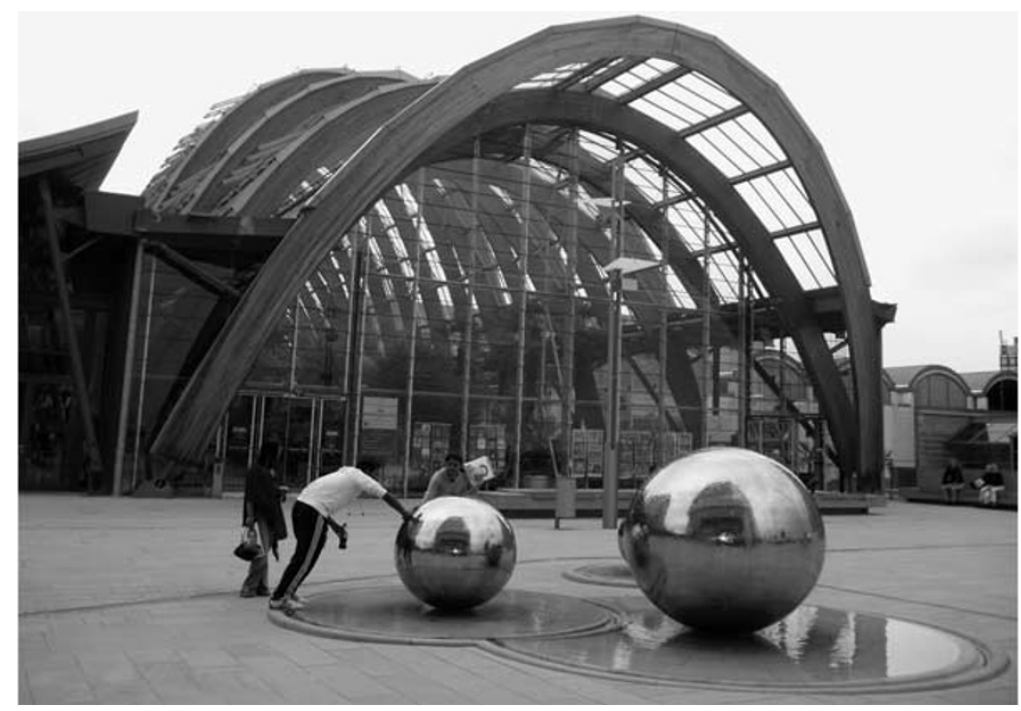

Figure 2: The Winter Garden 
reported top rents at $£ 14$ per square metre in 2003, this clearly impacts on the investment that developers are prepared to make in new office space, such as No 1 St Paul's Place and the subsequent quality of the building.

The economic reality is also a major factor in the hotel having only a 4-star rating. The masterplan envisaged a 5-star hotel but Sheffield's business community is not yet sufficient to support a city centre 5-star hotel. This perception of Sheffield as a secondary city has been reinforced through arguments that inward investment and visible regeneration should be encouraged at any cost. This has been played out in political differences between the local Labour and Liberal Democrats over issues, such as a proposed Ikea store and the listing of Park Hill Flats (the largest grade $2 *$ listed structure in Europe). Consequently, Sheffield occupies a weaker economic position that has clear impacts on the quality, scale and nature of regeneration that can occur within the city. Places, however, should not only be created or conceptualised in economic terms. Minton has argued for the need to guard again the production of homogeneous and bland spaces proposing that ' $[\mathrm{T}]$ he drive towards creating place purely as a consumer product contradicts the creation of a sense of place'(Minton, ${ }^{42} \mathrm{p} 30$ ) and that '[T] he problem is that current approaches to creating places seem to be too narrowly focused on only this aim, missing out in other aspects of the process essential to creating successful places.' (Minton, ${ }^{42} \mathrm{p}$ 26). The more recent commercial spaces, including the new office block and the Macdonald hotel, however, question how far the principle of 'a socially and economically accessible city centre' has been achieved.

This is illustrated by the relationship of the hotel with the Winter Garden. The Winter Garden is described by Sheffield city council as an example of stunning architecture; a place for people to relax and a venue, which is accessible to everyone in Sheffield. Thus, as a free entry venue, it is open to everyone, at least in theory. The national press described the Winter Garden and adjoining Millennium Galleries as 'bringing together clear-spirited, clean-cut architecture and high quality art of every sort' and as a 'brave and popular new complex of permeable, public city centre buildings', which the author hopes will be replicated in other cities in the UK. ${ }^{43}$ The Winter Garden has largely been seen as a success story, providing a covered public space, which also links the Peace Gardens to the Millennium Galleries and onwards to the CIQ and Sheffield's train and bus stations. Indeed, the Winter Garden may serve as a gateway to the exhibitions in the Millennium Galleries for non-traditional audiences.

The Winter Garden has won a number of architectural awards, but prominent views of it have been obscured by the Macdonald Hotel, which, as Figure 3 illustrates, is constructed from less innovative materials. In the masterplan, the Winter Garden 'was intended to be partly hidden and "discovered" by catching glimpses of it from the Peace Gardens, thereby encouraging people to walk through' ${ }^{44}$ Yet, as the public cultural attractions were completed before the private sector developments, residents did enjoy full views of the Winter Garden for over three years, before the building was obscured. 


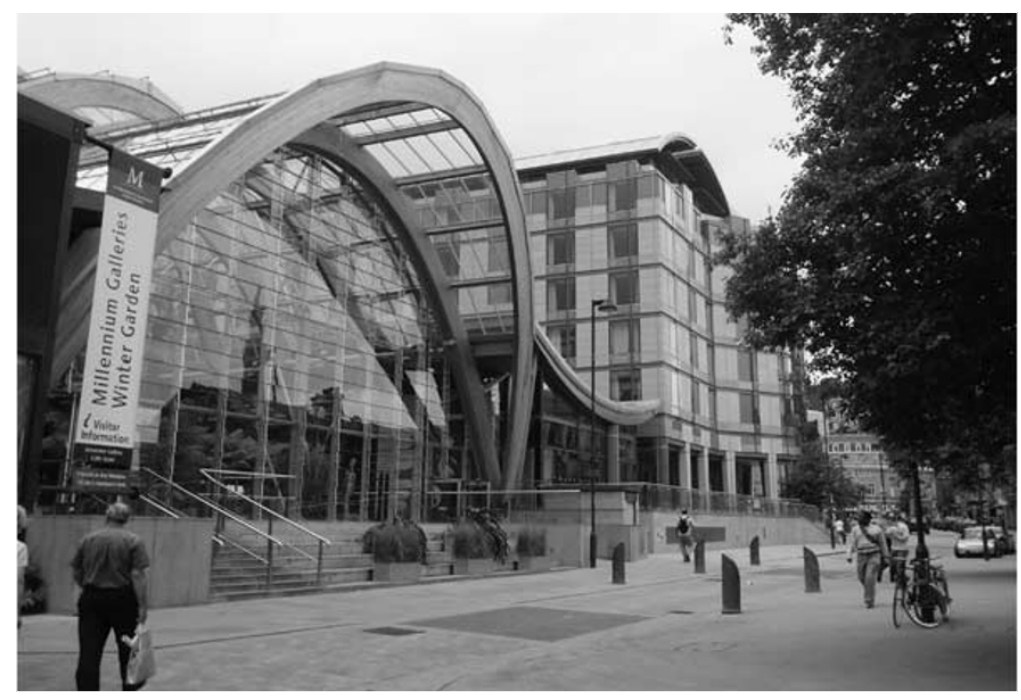

Figure 3: The Winter Garden with the Macdonald Hotel

Secondly, the hotel's lobby and restaurant sit adjacent to the Winter Garden with through access, allowing hotel patrons uninterrupted views onto this civic space (and vice versa), which compromises the public nature of this space. Ironically, the Winter Garden can only be enjoyed after $6 \mathrm{pm}$ by eating in the hotel restaurant as the Garden itself is closed to the public at that time. The Macdonald Hotel, which sits between the Grade 1 listed town hall and the award winning Winter Garden, is envisaged in the masterplan as being a 5-star hotel. Gaining a 5-star hotel was perceived to be vital to Sheffield positioning itself as attractive for business, as the city currently has no five-star hotels. Notably, the approval of the hotel did not include the provision of a Section 106 agreement to contribute financially to the maintenance of the Winter Garden, which demonstrates the difficulties of negotiating contributions to public funds from the private sector in more marginal cities. ${ }^{45}$

Number One St Paul's Place is located in a prime office development location in the city and marketed as a 'stunning new development' (Sheffield First, ${ }^{8}$ p 24) and will eventually provide 200,000 square feet of space. The first of the series of three office buildings arguably demonstrates poor quality design (see Figure 4), a concern raised by CABE in their review of the project's design. ${ }^{46}$ Indeed, councillors originally rejected the plans for the office block, and the revised plans were only approved by a narrow majority. ${ }^{47}$ Yet, the ground floor restaurants and bars will be able to enjoy the high quality public spaces provided through the URC.

In spite of these limitations, how accessible have the 'successful' Millennium Galleries and the Winter Garden actually been in reality? SGMT have pursued several projects aimed at engaging a wide range of socio-economic groups. While interviews with both repeat and first time visitors to the Millennium Galleries show that the special exhibition program at the galleries does attract different audiences, both repeat and first time visitors do tend to conform to the regular cultural consumer: the service class. ${ }^{48}$ 


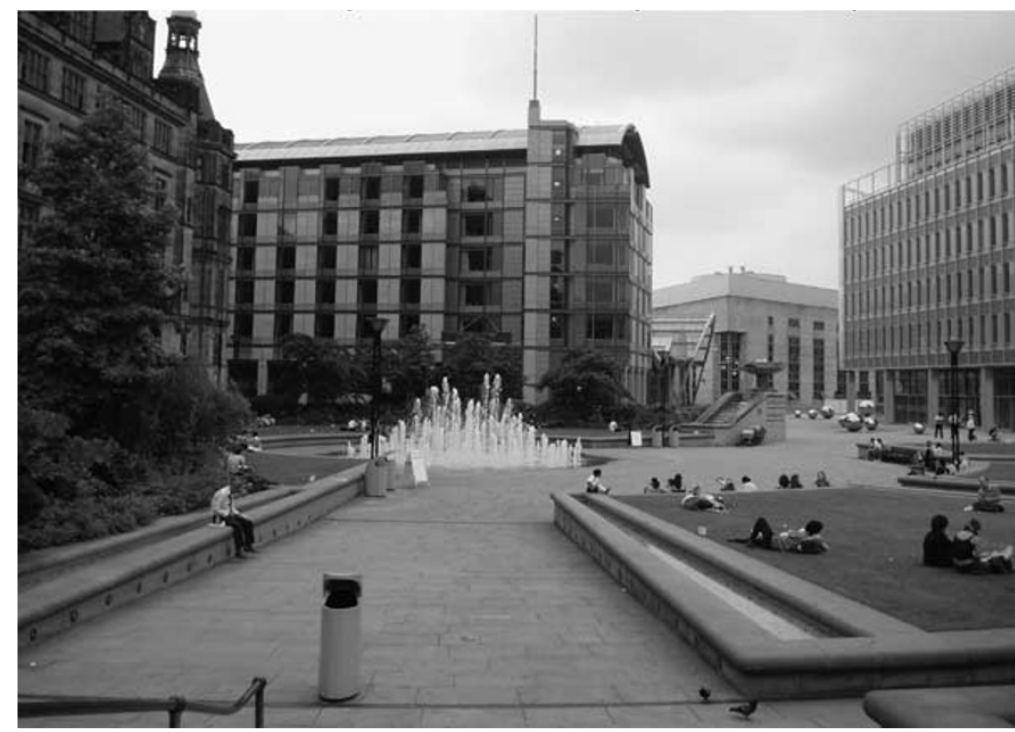

Figure 4: The Peace Gardens showing the Macdonald Hotel, with Number One St Paul's Place on the far right, the tallest building in Sheffield city centre.

In addition, a survey of visitors to the Winter Garden conducted shortly after it opened found that the visitor age profile was similar to that of typical cultural audiences. ${ }^{49}$ Students, mothers with young children and people aged over 65 years were the largest segments of visitors. In terms of occupation, again students and retired people formed large segments as did professionals and business managers, suggesting that the gardens provide somewhere quiet and covered for people to enjoy their lunch or a break from work. The visitors were, however, fairly diverse, with only 87 per cent of visitors describing themselves as white, compared to 91 per cent of Sheffield's population in the 2001 census. ${ }^{50}$ Ethnicity may be skewed by the high proportion of student visitors as both universities have large numbers of international students. The largest groups of visitors came from the postcode areas S2, S10 and S11, accounting for 30 per cent of the total number of visitors. While S10 and S11 are both affluent areas of the city with high student populations, S2 has a more varied population including areas with high unemployment and ethnic diversity. The postcode areas S6, S7 and S8 accounted for a further 20 per cent of visitors. These postcodes (S10 and S11) do include some of the most affluent areas outside London, but S6 is one of the poorer areas close to the city centre, and is now increasingly popular with students due to this proximity.

The survey results suggest that the Winter Garden has attracted a wider range of visitors than simply the service class. A problem with these findings, however, is that the Winter Garden provides a walkway between Sheffield Hallam University and the city centre, and the high number of student respondents may have skewed the sample to sound more inclusive than it really is.

\section{DISCUSSION AND CONCLUSIONS}

Has the Heart of the City masterplan delivered its vision? There are new, award-winning public spaces, but while these are open to all, it appears 
that they are not used by all. More significantly, how do the private spaces have impact on use of the public spaces? The new public spaces in Sheffield's city centre are the subject of surveillance with various guidelines about the types of behaviour that may or may not be acceptable. They offer a particular type of public space coterminous with the type of activities going on in the private spaces surrounding them; for example, St Paul's Place markets the area as having a 24-h-managed environment. Managed environments are not solely the preserve of public space, and it is argued that they should not necessarily be assumed to be negative or only of benefit to such groups. ${ }^{51}$ Indeed, 'Local economic prosperity and investment are, in part, predicated on attractive urban spaces that may drive responses that clear or bar undesirable users.' (DiGaetano and Lawless, ${ }^{51} \mathrm{p}$ 1840). While issues of safety are important, it must be borne in mind that the development occupies an area, which was wholly public open space, including local authority offices, and that the private sector's ownership of such spaces should be handled with sensitivity and responsibility towards all of the city's residents, not just those to whom it is marketable.

These private businesses, which incorporate bars and restaurants, enjoy the benefits of the publicly funded public realm improvements, but perhaps compromise these public spaces and this is of concern. While Bell $^{13}$ identifies consumptive uses to be one of the critical factors for masterplanning, it is evident that such activities are only accessible to certain sectors of society, and their juxtaposition with open spaces acts to create an invisible but clear barrier. So contemporary masterplanning even under a Labour council is still unable to integrate lower income and excluded groups within the city. ${ }^{20}$ Furthermore, this raises questions about the meaningfulness of partnerships between the public, private and voluntary sectors in redeveloping neighbourhoods if perceptions are that private enterprise will benefit from such improvements to the physical realm at the expense of local residents.

There is no doubt that Sheffield city centre is a more aesthetically pleasing place to be with more and better quality cultural spaces. The URC is widely viewed as successful, particularly in partnership and innovative working. While we have no empirical evidence of this, the Winter Garden must surely contribute to residents' pride in their city, ${ }^{22}$ not least by its feting in the national media. These developments have gone some way to redress the problems caused by the earlier phase of cultural planning, with the CIQ and National Centre for Popular Music, which failed to provide good cultural spaces. If we compare the outcomes of the Heart of the City masterplan with Sheffield First's 12 features of a successful city, we can see that on most levels Sheffield One has delivered. But how inclusive is Sheffield city centre today? Has the new cultural regeneration helped integrate the low income and ethnic minority groups that Bianchini found were excluded culturally, socially and spatially ${ }^{20}$ ? Can a public space be inclusive simply because it is free to visit?

Sheffield city centre is still for and dominated by the service class. This has been compounded by a housing policy, which has seen the development of huge numbers of city centre luxury flats, 'exclusive 
apartments and designer loft-style living, 52 with over 1,300 built and another 1,100 planned in $2003,{ }^{53}$ still more built since and other similar developments planned. City centre living for the service class has been encouraged by the licensing of several new bars and restaurants in the city centre. Even a free access venue such as the Winter Garden, which at a superficial level demands little cultural capital to enjoy, attracts business people in their lunch hour, students and residents from the more affluent areas of Sheffield. Residents from lower income groups are still more likely to frequent areas with cheaper shops, on the periphery of the 'heart' of the city, although these peripheral areas will soon be redeveloped as further stages of the overall city centre masterplan. Part of the strategy does recognise the need to improve transportation to the city centre and the permeability of the city centre, but it is acknowledged that different areas will be prioritised by different groups. ${ }^{54}$

Is Stevenson's ideal of an inclusive cultural planning an unrealisable construct? Sheffield's planning seems rooted within the cultural planning discourse of the 1980s, but without private sector investment, how would these public spaces be funded? If we re-examine Amin et al's statement that 'All spaces embody power relations of some sorts...' (Amin et al., ${ }^{12}$ p 12) do we conclude that the power relations here are about how the public and private sector regard each other? The private sector has not delivered buildings within public spaces that are comparable to public spaces, such as the Peace Gardens and Winter Garden, but they were still granted planning permissions. This paper does not argue for a utopian vision of the city removed from economic realities. Rather, it aims to emphasise that schemes involving the public sector and public realm need to take into account the responsibilities to all sectors of a population, not just those that contribute to profits. While the private sector has gone some way to engaging with the challenges of community consultation, ${ }^{55}$ public spaces are not neutral places open to all and no one vision of a city can include everyone ${ }^{55}$ Yet that does not negate the necessity of further debate.

'[T]he therapeutic properties of public spaces are not reducible to a set of design-based, natural or aesthetic criteria. One can design a public space to the highest standards and provide top-quality facilities in order to create the potential for well-being to be experienced without delivering the social benefits a space can provide; ultimately it is what goes on within a space that is important.'(Dines et al., ${ }^{66} \mathrm{p}$ 39)

Cultural regeneration can make a city a more attractive place to live and work, and the city council's investments in public spaces such as the Millennium Galleries and Winter Garden help to contribute to this. Unfortunately, this means that the public sector has to subsidise the private sector by creating a better environment, with higher property rents and yields. In spite of their cultural policy statements, Sheffield city council's cultural plans are still economically driven, as they were in the 1980s, and local residents both gain and lose by this process. There is evidence that this policy is at least achieving some success, with Sheffield's image beginning to change outside the region. Knight 
Frank continues to direct attention to the benefits of investment in this regenerating area. ${ }^{53}$ The first speculative office development in Sheffield for several years has begun at the far end of the city centre, close to transport links. Additionally, the new retail quarter, which is the next stage of the masterplan and adjoins the Heart of the City, has won the Building Exchange award for the best masterplan for regeneration in June $2006^{57}$ and so, there is hope for these future developments. Since the masterplan is being implemented over an extended timescale of 10-15 years, it seems that this current redevelopment is an organic process. By the time the final stages are implemented, the initial developments may have caused rents to rise even further, meaning that more can be demanded from the private sector. This case study should be revisited then to assess the long-term impact of these redevelopments and how these public cultural spaces will be used in the future.

\section{References}

1. Richards, G. (ed.) (2001). Cultural Attractions and European Tourism, CAB International, Wallingford, Oxon.

2. Office of National Statistics (2005). 2004 Mid Year Population Estimates, Sheffield, ONS, London.

3. Moss, L. (2002). Sheffield's cultural industries quarter 20 years on: What can be learned from a pioneering example? International Journal of Cultural Policy. 8(2), 211-219.

4. Table 101: Dwelling stock by tenure, United Kingdom, http://www.communities.gov.uk/pub/7/ Table101_id1156007.xls Department of Communities, Local Government and the Regions, Accessed 7th August 2006.

5. DiGaetano, A. \& Lawless, P. (1999). Urban governance and industrial decline: Governing structures and policy agendas in Birmingham, Sheffield, England and Detroit, Michigan, 1980-1997. Urban Affairs Review. 34(4), 546-577.

6. Chatterton, P. \& Unsworth, R. (2004). Making space for culture(s) in Boomtown. Some alternative futures for development, ownership and participation in Leeds City Centre. Local Economy. 19(4), 361-379.

7. Dabinett, G. (2004). Creative Sheffield: Creating values and changing values? Local Economy. 19(4), 414-419.

8. Sheffield First (2005). Prime Office Sites in Sheffield, Sheffield First, Sheffield.

9. Brown, A., O’Connor, J. \& Cohen, S. (2000). Local music policies within a global music industry: Cultural quarters in Manchester and Sheffield. Geoforum. 31, 437-451.

10. Evans, G. (2001). Cultural Planning: An Urban Renaissance, Routledge: London.

11. The Winter Garden, Sheffield City council, http://www.sheffield.gov.uk/out--about/city-centre/ the-winter-garden Accessed 1st September 2006.

12. Amin, A., Massey, D. \& Thrift, N. (2000). Cities for the Many not the Few, The Policy Press, Bristol.

13. Bell, D. (2005). The emergence of contemporary masterplans: Property markets and the value of urban design. Journal of Urban Design. 10(1), 81-110.

14. Bianchini, F. (1993). Remaking European cities: The role of cultural policies in Bianchini, F. \& Parkinson, M. (eds) Cultural Policy and Urban Regeneration: The Western European Experience, Manchester University Press, Manchester, pp 1-20.

15. Voase, R. (1997). The role of flagship cultural projects in urban regeneration: A case study and commentary. Managing Leisure. 2, 230-241.

16. Plaza, B. (2000). Evaluating the influence of a large cultural artefact in the attraction of tourism: The Guggenheim Museum Bilbao case. Urban Affairs Review. 36(2), 264-274.

17. Plaza, B. (1999). The Guggenheim-Bilbao Museum effect: A reply to Maria V. Gomez' 'Reflective images: The case of urban regeneration in Glasgow and Bilbao'. International Journal of Urban and Regional Research. 23(3), 589-592.

18. Gomez, M.V. (1998). Reflective images: The case of urban regeneration in Glasgow and Bilbao. International Journal of Urban and Regional Research. 22(1), 106-121.

19. McNeill, D. (2000). McGuggenisation? National identity and globalisation in the Basque country. Political Geograph. 19, 473-949.

20. Bianchini, F. (1993). Issues and prospects for the 1990s in Bianchini, F. \& Parkinson, M. (eds) Cultural Policy and Urban Regeneration: The Western European Experience, Manchester University Press, Manchester, pp 199-213. 
21. Stevenson, D. (2004). Civic gold rush: Cultural planning and the politics of the Third Way. International Journal of Cultural Policy. 10(1), 120-131.

22. Bailey, C., Miles, S. \& Stark, P. (2004). Culture-led urban regeneration and the revitalisation of identities in Newcastle, Gateshead and the North East of England. International Journal of Cultural Policy. 10(1), 47-65.

23. Colls, R. \& Lancaster, B. (1992). Geordies: Roots of Regionalism, Edinburgh University Press, Edinburgh.

24. Commission for Architecture and the Built Environment (2006). Who We Are. What We Do. Why It Matters, CABE, London.

25. Walzer, M. (1986). Pleasures and costs of urbanity. Dissent. 33(4), 470-475.

26. Betterton, R. \& Blanchard, S. (1992). Made in Sheffield: Towards a Cultural Plan for Sheffield in the $1990 \mathrm{~s}$, Sheffield City council, Sheffield.

27. Luck and Brass, http://arts.guardian.co.uk/features/story/0,,1342950,00.html, The Guardian, Accessed 1st September, 2006.

28. Roodhouse, S. (2000). The wheel of history - A relinquishing of city council cultural control and the freedom to Management: Sheffield Galleries and Museums Trust. International Journal of Arts Management. 3(1), 78-86.

29. Black, G. (1999). Pulling in the visitors. Museums Journal. 99(12), 14-15.

30. Gosse, A. (2006). Sheffield Culture: A Strategy For Inclusive Cultural and Sporting Development, Sheffield City council, Sheffield.

31. Keeble, L. (1961). Town Planning at the Cross-Roads, Walker and Co Ltd, Twickenham.

32. Healey, P. (1997). Collaborative Planning: Shaping Places in Fragmented Societies, Macmillan Press Ltd, Basingstoke.

33. Office of the Deputy Prime Minister (2004). Urban Regeneration Companies - Policy Stocktake (Final Report), ODPM, London.

34. Sheffield First Partnership (2006). Sheffield's Future: Be Part of It - Sheffield City Strategy, Sheffield First, Sheffield.

35. Sheffield One (2005). Creative Sheffield: Transforming Sheffield's Economy, Sheffield First Partnership, Sheffield.

36. Urban Regeneration Companies, http://www.englishpartnerships.co.uk/urcs.htm English Partnerships, Accessed 4th August 2006.

37. Fainstein, S. (2001). The City Builders: Property Development in New York and London 1980-2000 (Second Edition, Revised), University Press of Kansas, Kansas.

38. Hart, A. (2003). A neighbourhood renewal project in Dalston, Hackney: Towards a new form of partnership for inner city regeneration. Journal of Retail and Leisure Property. 3(3), 237-245.

39. Koetter Kim \& Associates (2000). Masterplan Report, Koetter, Kim and Associates (UK) Ltd, London.

40. St Paul's Place Masterplan, http://www.stpaulsplace.co.uk/masterplan.htm, CTP Limited and St James Securities, Accessed 4th August 2006.

41. Town Reports, Leeds, Manchester, Sheffield, http://www.focusnet.co.uk/srch_tfocus.cfm?new=1 Focus, Accessed 3rd August 2006.

42. Minton, A. (2006). The Privatisation of Public Space, RICS, London.

43. Underneath the arches, http://arts.guardian.co.uk/critic/feature/0,869591,00.html, The Guardian, Accessed 1st September, 2006.

44. Heart of the City, http://www.sheffield1.com/heart.html Sheffield One, Accessed 1st September, 2006.

45. Personal Communication, Sheffield City council, City centre and East Development Control Team, 4th September 2006.

46. Design Review, http://www.cabe.org.uk/default.aspx ?contentitemid=861\&field=filter\&term= Commercial\&type $=7$ CABE, Accessed 1st September 2006.

47. City Reaches for the Sky, http://www.sheffieldtoday.net/ViewArticle2.aspx?sectionid= 58\&articleid=1224409, Sheffield Telegraph, Accessed 5th September 2006.

48. Holmes, K. (2003). Regular and irregular visitors to the Millennium Galleries, Sheffield in Snape, B., Thwaites, E. \& Williams, C. (eds) Access and Inclusion in Leisure and Tourism, Leisure Studies Association, Eastbourne.

49. Holmes, K. (2006). Cultural regeneration for local residents? The case of the Millennium Galleries and the Winter Garden, Materialising Sheffield: Place, Culture and identity. Humanities Research Institute, University of Sheffield.

50. Ethnic Group, http://www.neighbourhood.statistics.gov.uk/dissemination/LeadTableView.do?a=3 $\& \mathrm{~b}=276794 \& \mathrm{c}=$ sheffield $\& \mathrm{~d}=13 \& \mathrm{e}=15 \& \mathrm{~g}=365736 \& \mathrm{i}=1001 \times 1003 \times 1004 \& \mathrm{~m}=0 \& \mathrm{enc}=$ $1 \& d s F a m i l y I d=47$ Neighbourhood Statistics, Accessed 7th September, 2006.

51. Atkinson, R. (2003). Domestication by Cappuccino or a revenge on urban space? Control and empowerment in the management of public space. Urban Studies. 40(9), 1829-1843. 
52. Sheffield City Guide, http://www.british-publishing.com/Pages/Sheffield/city.html Sheffield City council, Accessed 1st September 2006.

53. Knight Frank (2003). Sheffield: Central Area Activity Report: Spring 2003, Knight Frank, London.

54. Instone, P. \& Roberts, G. (2006). Progress in retail led regeneration: Implications for decisionmakers. Journal of Retail and Leisure Property. 5(2), 148-161.

55. Emery, J. (2006). Bullring: A case study of retail-led urban renewal and its contribution to city centre regeneration. Journal of Retail and Leisure Property. 5(2), 121-133.

56. Dines, N., Cattell, V., Gesler, W. \& Curtis, S. (2006). Public spaces, social relations and wellbeing in East London, The Policy Press, Bristol.

57. Sheffield masterplan recognised by BEX, http://www.bdp.co.uk/html/news/2006/Sheffield Masterplan_recognised_by_BEX_166.asp, Business Design Partnership, Accessed 5th October 2006. 